\title{
Antimicrobial stewardship in hospitals in Latin America and the Caribbean: a scoping review
}

\author{
Jennifer Hegewisch-Taylor, ${ }^{1}$ Anahí Dreser-Mansilla, ${ }^{1}$ Julián Romero-Mónico, ${ }^{1}$ and Gabriel Levy-Hara²
}

Suggested citation Hegewisch-Taylor J, Dreser-Mansilla A, Romero-Mónico J, Levy-Hara G. Antimicrobial stewardship in hospitals in Latin America and the Caribbean: a scoping review. Rev Panam Salud Publica. 2020;44:e68. https://doi.org/10.26633/RPSP.2020.68

ABSTRACT Objectives. To examine published antimicrobial stewardship (AMS) initiatives in hospitals in Latin America and the Caribbean (LAC) in order to characterize AMS terminology usage, geotemporality, and elements of structure (human resources), process (interventions), and outcomes, and to set priority areas for improving AMS reporting.

Methods. This was a scoping review that searched PubMed, LILACS, EMBASE, and 12 other databases, along with a manual search for academic and grey literature to identify documents on AMS initiatives in hospitals in 33 countries of LAC, up to August 2019. Keywords included 'antibiotic' or 'antimicrobial' AND 'stewardship, policy, strategies, management, control, rational use, appropriate use, surveillance, or interventions' and 33 country names.

Results. Selected articles totalled 147 studies published in 1985 - 2019; of those, 22\% used 'antimicrobial stewardship' in the title. Eighteen countries published AMS hospital initiatives, one-half of which were implemented in capital cities. Brazil, Argentina, Colombia, Cuba, Mexico, and Chile, in descending frequency, made up $>59 \%$ of published initiatives. Educational interventions were the most frequently reported, followed by persuasive and restrictive strategies. Antimicrobial consumption was the most common outcome measure reported. About one-third of the studies (35\%) referred to baseline measures-only in preparation for AMS interventions. Fifty-nine studies from 6 countries reported AMS comprehensively, using structure, process, and outcome (SPO) elements.

Conclusions. Published hospital AMS initiatives have increased over time and have expanded across LAC. However, more programs need to be developed. Complete reporting of SPO elements is imperative to evaluating and replicating AMS actions.

Keywords Antimicrobial stewardship; drug resistance, microbial; hospital; Latin America; Caribbean region.

The overuse, misuse, and abuse of antimicrobials have been acknowledged as key drivers of the global emergence of antimicrobial resistance (AMR), both in the community and in hospitals. The rate of inadequate antimicrobial use in hospitals has been calculated to be $50 \%$ (1), which explains why inpatient settings have been targeted with an assortment of interventions-antimicrobial stewardship (AMS) initiatives, including antimicrobial stewardship programs (ASPs) to optimize antimicrobial use, including selection, dose, duration, and route of administration (2). The main purpose of AMS is to improve patient outcomes, decrease unintended effects of antimicrobial use, counteract AMR, as well as to provide cost-effective health care $(3,4)$. With this aim, the World Health Organization (WHO) has described the main elements of AMS (4): establishing an AMS structure with formal leadership support and dedicated human resources; implementing interventions that improve antimicrobial prescribing practices (educational, persuasive, or feedback

\footnotetext{
1 Health Systems Research Center, National Institute of Public Health, Cuernavaca, Mexico. $₫$ Anahí Dreser Mansilla, anahi.dreser@insp.mx
} 
opportunities); restrictive and structural interventions; and metrics to assess improvement of the structures, processes, and outcomes (SPOs).

ASPs have been increasingly implemented around the world in the form of an heterogenous mix of individual AMS interventions and bundled strategies that have been adapted to different health care systems $(5,6)$. High-income countries (HICs), such as the United States and several in Europe, have successfully implemented ASPs (7). However, less is known about hospital AMS in low- and middle-income countries (LMICs), such as in Latin America and the Caribbean (LAC) where different socioeconomic contexts exist (8).

One of the first AMR regional studies of Latin America was conducted by Curcio and colleagues (9) who performed 1-day point prevalence studies in $2008-2010$ to evaluate antibiotic use in intensive care units (ICUs). In 2012, Howard and colleagues (10) performed the first global survey to describe the extent and the components of hospital ASPs. Of the total survey respondents, 103 were from Central and South America, $46 \%$ of which reported having had an ASP of some kind for an average of 3 years.

Several reviews and surveys of AMR $(11-13)$ have been conducted, but few publications have focused on LAC, compared to other regions. Most have excluded the so-called grey literature (non-indexed journals, conferences, and theses), which presumably includes descriptions of AMS experiences that remain unpublished due to a lack of resources or overall operational capacity. Additionally, it is likely that these initiatives use a wide variety of ASP terminology since language translations have not been standardized (2). Therefore, developing a scoping review to map the existing AMS literature in terms of the volume, nature, and characteristics of primary research (14) may be valuable.

This scoping review aimed to examine published AMS initiatives in hospitals in Latin America and the Caribbean to characterize terminology usage, geo-temporality, and elements of structure (human resources), process (interventions), and outcomes, and to identify priority areas for improving AMS reporting.

\section{MATERIALS AND METHODS}

\section{Search strategy}

A systematic scoping review of academic and grey literature (posters, conference abstracts, and theses) was performed in accordance with the Preferred Reporting Items for Systematic Reviews and Meta-Analyses (PRISMA) standards for scoping reviews (15).

The following indexed and non-indexed databases were searched from inception to August 2019: MEDLINE ${ }^{\circledR} /$ PubMed Central (U.S. National Library of Medicine, Bethesda, MD, United States); LILACS (Latin American and Caribbean Center on Health Sciences Information, PAHO/WHO, São Paulo, Brazil); EMBASE (Excerpta Medica Database, Elsevier, Amsterdam, the Netherlands); CENTRAL (Cochrane Central Register of Controlled Trials, London, United Kingdom); Scopus (Elsevier, Amsterdam, the Netherlands); CINAHL (Cumulative Index to Nursing and Allied Health Literature, Ipswich, MA, United States); IMBIOMED (Mexican Index of Latin American Biomedical Journals, Mexico); Medigraphic (Index of biomedical literature including research papers, Mexico); Redalyc (Network of Scientific Journals, Autonomous University of the State of Mexico, Mexico); SciELO (Scientific Electronic Library Online, Latin American and Caribbean Center on Health Sciences Information, São Paulo, Brazil); Latin American Repositories Network (Universidad de Chile, Santiago, Chile); and The Virtual Health Library (VHL, accessing national databases of scientific publications in Argentina, Cuba, and Jamaica).

The review included a manual search for titles relevant to the topic through October 2019 using Google Scholar (Google Inc., Mountain View, California, United States).

The search strategy used a combination of first- and secondstring terms. The first string was composed of keywords associated with antimicrobial stewardship, 'antibiotic' or 'antimicrobial' AND 'stewardship, policy, strategies, management, control, rational use, appropriate use, surveillance, or interventions' and subject headings, such as 'Antimicrobial Stewardship' and 'Drug Utilization Review' (6). The second string terms included 33 countries of LAC: Antigua and Barbuda, Argentina, Bahamas, Barbados, Belize, Bolivia, Brazil, Chile, Colombia, Costa Rica, Cuba, Dominica, Dominican Republic, Ecuador, El Salvador, Granada, Guatemala, Guyana, Haiti, Honduras, Jamaica, Mexico, Nicaragua, Panama, Paraguay, Peru, Saint Kitts and Nevis, Saint Vincent and the Grenadines, Santa Lucia, Suriname, Trinidad and Tobago, Uruguay, and Venezuela. Non-self-governing territories were not included in this review. Terms were translated/adapted to French, Portuguese, or Spanish, according to the requirements of each database. The full strategy is available from the authors upon request.

\section{Study selection}

Initially, all documents (articles, reports, letters, editorials, comments, posters, theses, etc.) in English, French, Portuguese, or Spanish describing any AMS intervention (or program, strategy, policy, baseline assessment, etc.) aimed at responsible use of antimicrobials in hospitals or emergency departments were considered, even if the "ASP" label was not mentioned. The snowballing technique (16) was used to extract additional sources within secondary studies (reviews) and surveys. Studies excluded were those that: only described resistance levels or disease management not related to AMS; did not take place in a hospital or emergency department; referred to medicine other than antimicrobials; or reported on pharmacovigilance and pharmacoeconomics unrelated to an AMS intervention.

Duplicates were removed prior to the screening phase. Titles and abstracts were screened independently by JH and JR using Rayyan software (17); discrepancies were solved among all authors. Selected documents were reviewed for full-text eligibility. The complete list of selected articles can be found in this Google Drive folder ${ }^{3}$ or obtained from the authors upon request. The quality of the studies was not formally evaluated, consistent with a scoping review.

\section{Data collection, processing, and analysis}

All authors collaborated on extracting the following data variables from the selected documents: type of literature;

https://drive.google.com/file/d/1OWvTvi3ANQ5W7jpQdjoKUT1SNsrS cwRC/view?usp=sharing. 
year and language of publication; category of terminology used to refer to AMS in the title; country and city of involved hospitals; and AMS elements, i.e., human resources, type of intervention, and outcome and process measures. AMS terminology and frequency of publications were graphed by year of publication. When available, the geographic extent of AMS initiatives was mapped at country and city levels. Reporting of selected elements of structure (human resources), process (types of interventions), and outcome (process and outcome measures) were indicated by country. Interventions and outcome and process measures were classified according to WHO guidelines (4). The full-dataset is available from the authors upon request.

\section{RESULTS}

The search strategy identified 2444 relevant records, and another 34 were added manually, for a total of 2478 initial results. After duplicates were removed, 1872 records were screened. After excluding irrelevant titles, 563 abstracts were reviewed. Of those, 147 records (6\% of the total records) met the inclusion criteria. Academic literature accounted for 106 articles or reports; 41 (28\%) were grey literature, including conference posters, editorials, comments, and letters reporting on AMS interventions. Most (76 articles) were written in English, 56 in Spanish, and 15 in Portuguese. The PRISMA flow diagram (Figure 1) shows the review phases and results obtained.

FIGURE 1. PRISMA strategy flowchart for a systematic scoping review of antimicrobial stewardship (AMS) initiatives in hospitals in Latin America and the Caribbean

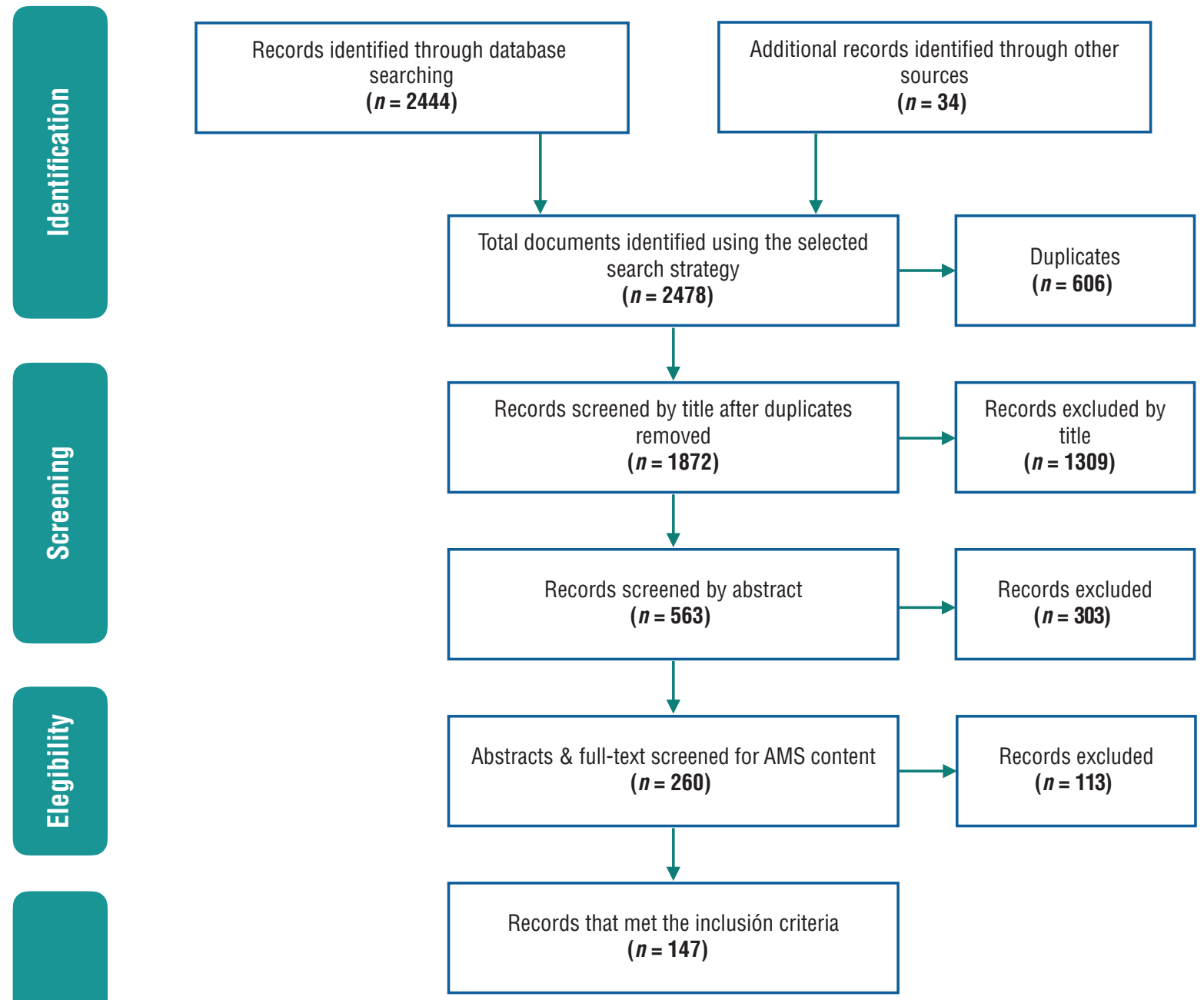

\begin{tabular}{c}
\hline Type of documents \\
Articles \& reports: 106 \\
Poster abstracts: 33 \\
Thesis: 3 \\
Editorial/Comment/Letter to \\
the editor: 5 \\
\hline
\end{tabular}

\begin{tabular}{|c|}
\hline Language \\
English: 76 \\
Spanish: 56 \\
Portuguese: 15 \\
\hline
\end{tabular}

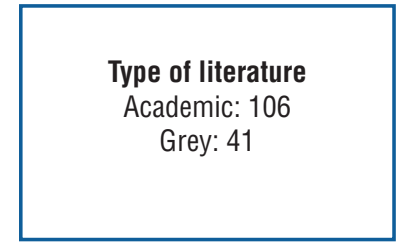

Source: Prepared by the authors from the study results.

PRISMA: Preferred Reporting Items for Systematic Reviews and Meta-Analyses 


\section{Antimicrobial stewardship terminology}

The need to counteract AMR with AMS initiatives is not recent; therefore, labels referring to related initiatives have been continuously evolving. In this review, we identified 81 publication titles using specific terminology referring to the optimization of antimicrobial use; these terms were classified into broad categories and their usage frequency was graphed over time (Figure 2). The category term most frequently used in these 81 titles was "antimicrobial / antibiotic stewardship" $(n=32)$, first used in 2010. It was followed by "control program" $(n=10)$, "rational use" $(n=9)$, "surveillance" $(n=8)$, "program to optimize / improve the use of antimicrobials / antibiotics" $(n=7)$, "intervention / strategy for the appropriate use" $(n=7)$, "policy on the use" $(n=5)$, and "reduction" $(n=3)$. The oldest category terms used were "reduction/restriction" and "control program on the use of antimicrobials/antibiotics."

\section{Antimicrobial stewardship temporal and geographic expansion}

Publication dates ranged from 1985 - 2019 (Figure 3). AMS publications increased steadily until 2009, and then sharply $(n=6)$ to a peak of 14 per year in 2017. The oldest publications on AMS initiatives were from Brazil and Colombia; whereas, the most recent came from countries that, according to this review, had not published on the topic before: Barbados and Santa Lucia.

Publications were found in 18 countries $(55 \%)$ of the 33 screened. Countries with the greatest numbers were, in descending frequency, Brazil, Argentina, Colombia, Cuba, Mexico, and Chile, which concentrated 59\% $(n=86)$ of the total $(n=147)$. One publication combined reports from three countries and could not be evaluated independently. Figure 4 displays the total number of publications found per-country

FIGURE 2. Evolution of the terminology used in the titles of publications related to antimicrobial stewardship initiatives in Latin America and the Caribbean

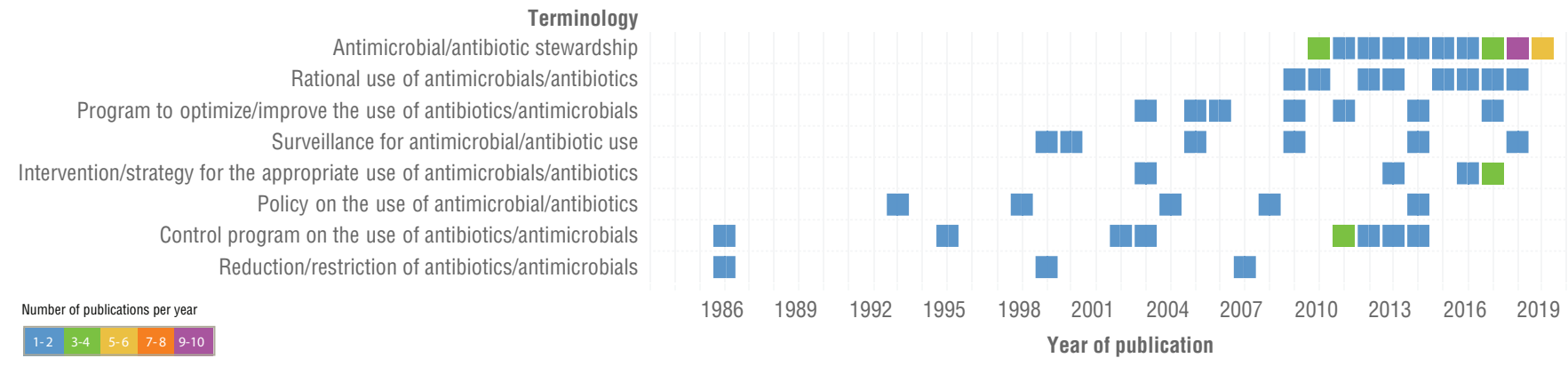

Source: Prepared by the authors from the study results

FIGURE 3. Publications of antimicrobial stewardship initiatives in hospitals in Latin America and the Caribbean per year, 1985 - 2019

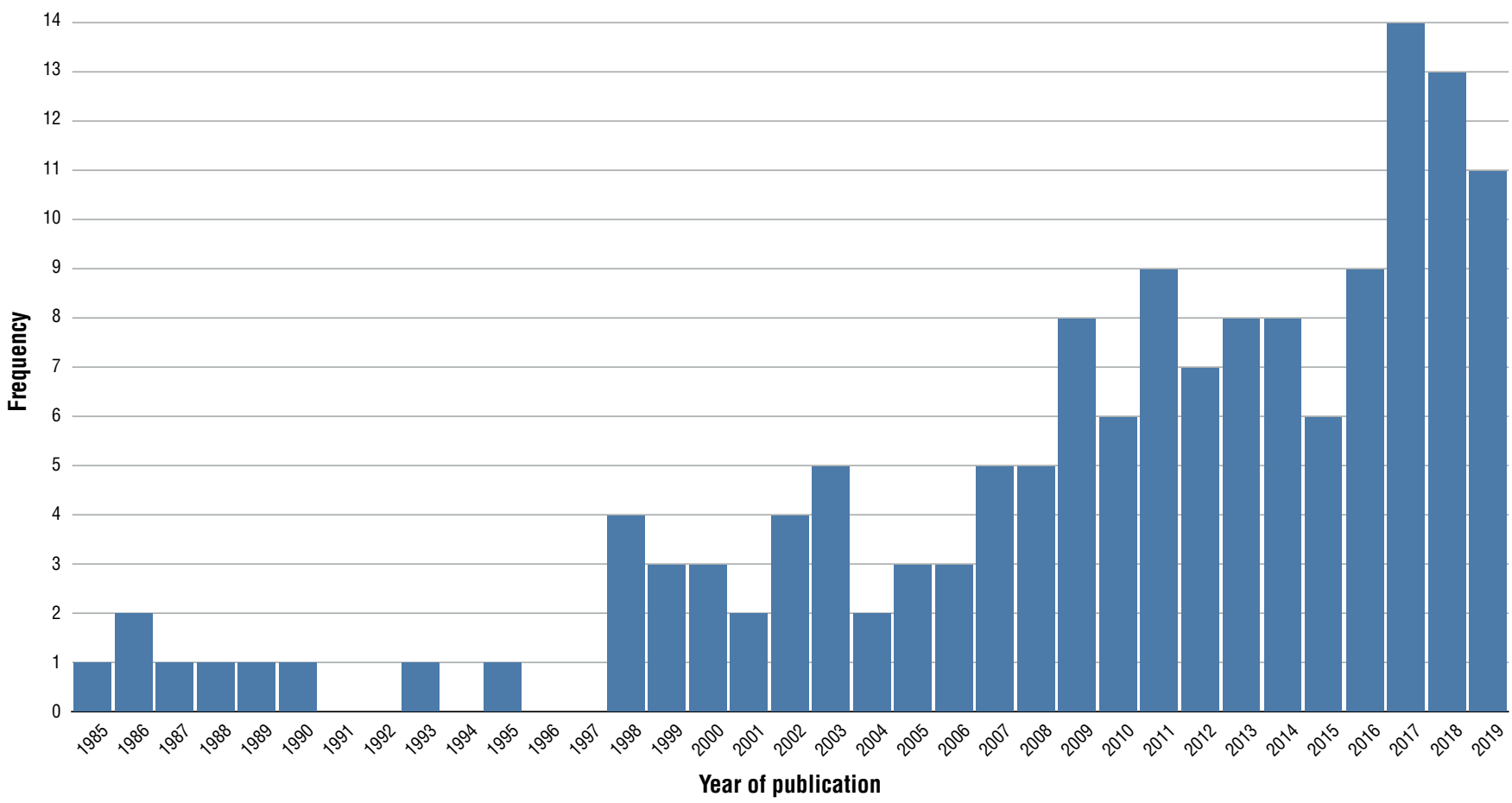

Source: Prepared by the authors from the study results. 
FIGURE 4. Density of publications by country, location of cities with antimicrobial stewardship initiatives and their reported elements in Latin America and the Caribbean, 1985 - 2019

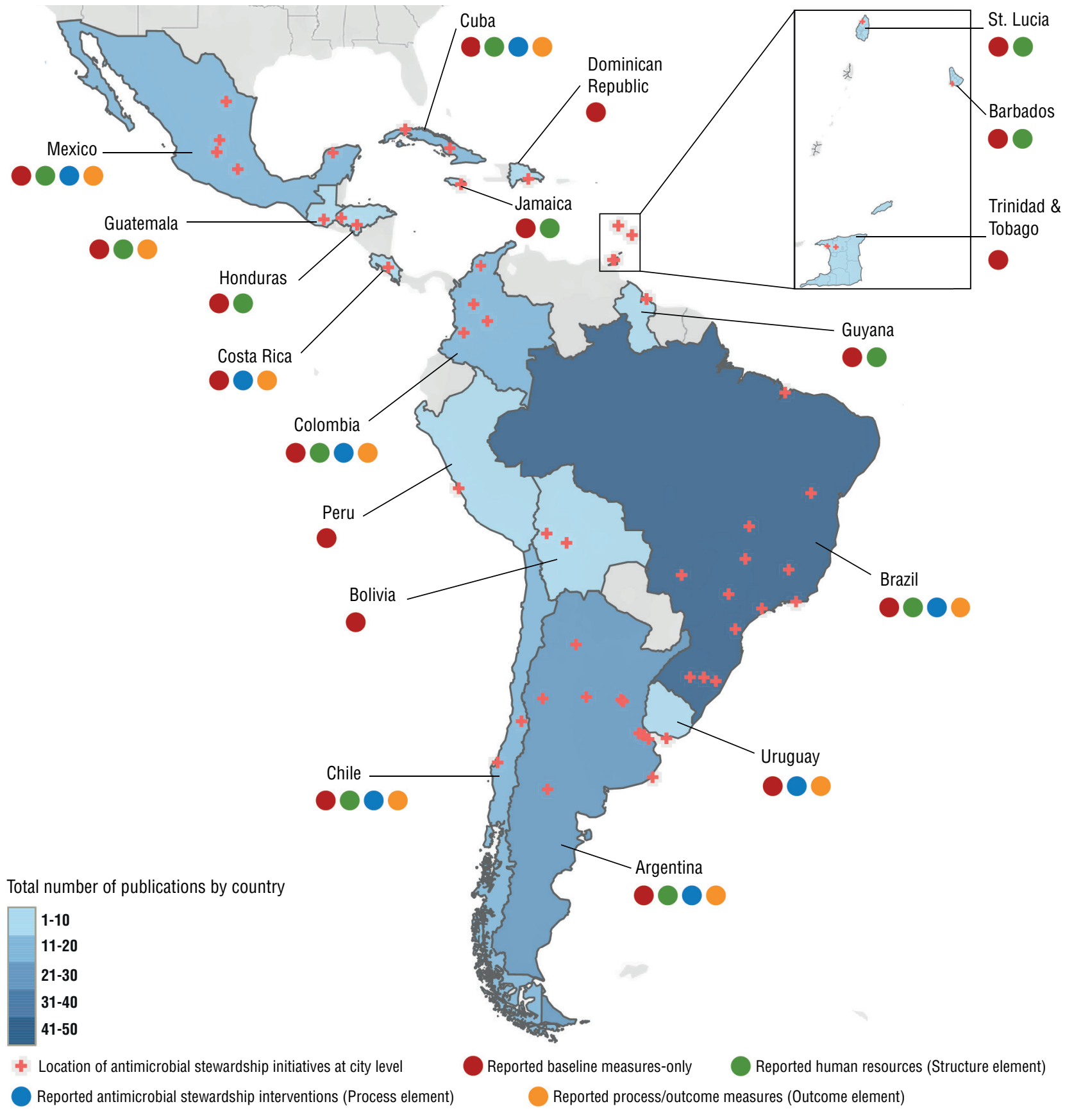

Source: Prepared by the authors from the study results.

and the 54 cities where AMS interventions took place. Almost one-half of them $(47 \%)$ were in capital cities.

\section{Characterization of antimicrobial stewardship in LAC}

Publications were examined to determine whether they reported on the SPOs per country (Table 1). Eighty-one of 147 publications from 12 countries reported on human resources involved in AMS. Many referred to different groups or structures (e.g., multidisciplinary teams, AMS or Infection Prevention and
Control committees), making it difficult to quantify the expertise of the members involved (e.g., infectious disease specialists, physicians, pharmacists, microbiologists, nurses).

Regarding process elements, $86(59 \%)$ listed an identifiable AMS intervention and many had more than one initiative. The most common were educational interventions, including training and dissemination of messages $(n=26)$ and implementation and dissemination of guidelines $(n=36)$. Forty-six $(31 \%)$ described persuasive or feedback interventions, such as audits to achieve de-escalation, dose-optimization, correcting 


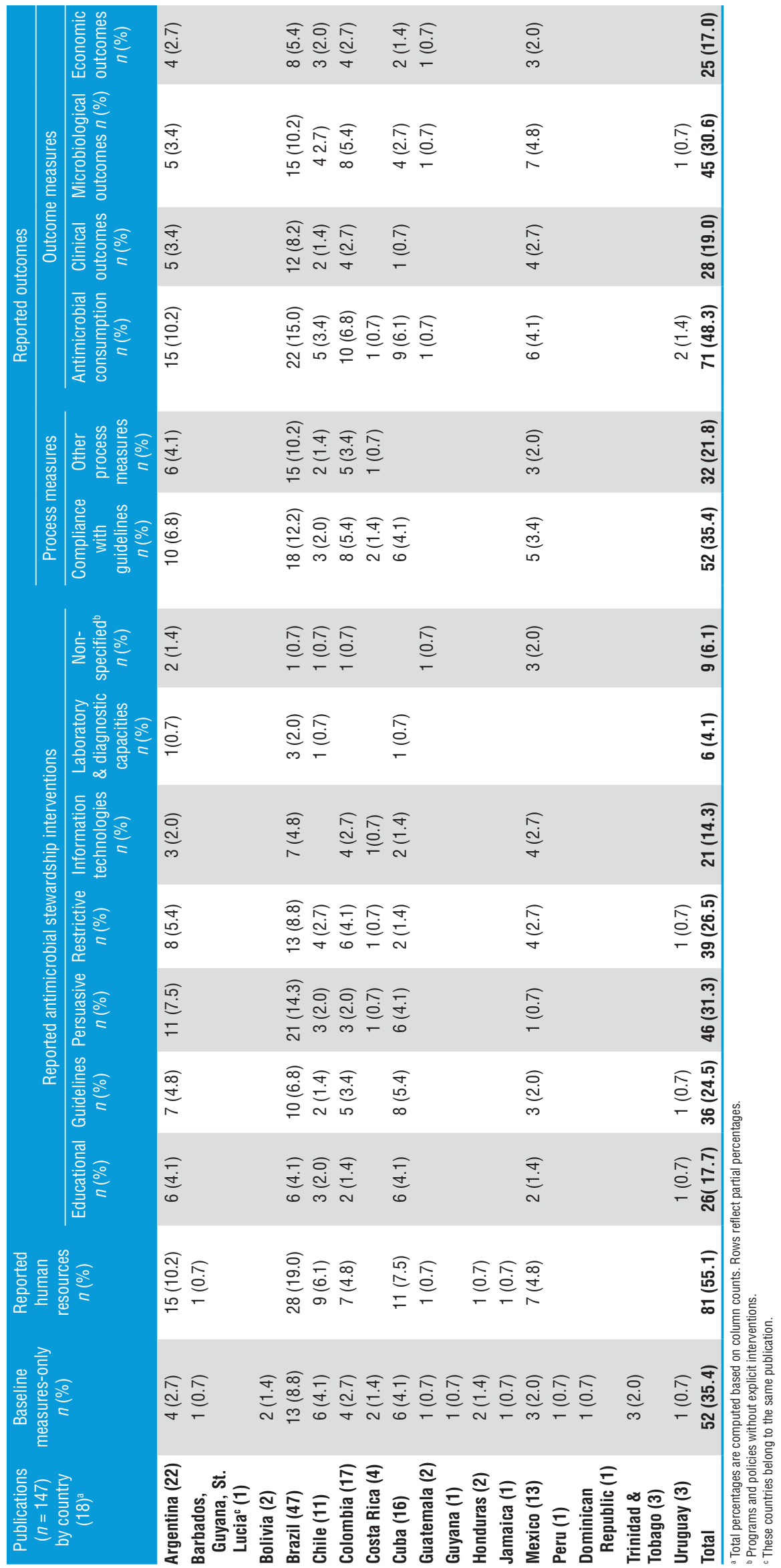


redundant therapy, intravenous-to-oral switch, or shorter length of treatment. Thirty-nine $(27 \%)$ studies described restrictive interventions, including the use of pre-authorization formularies, restricted dispensing of targeted antibiotics, or automatic stop orders. Structural interventions to use information technology for monitoring and supervising prescriptions, and to incorporate laboratory and diagnostic capacities (e.g., rapid laboratory testing, therapeutic drug monitoring, and computerized physician orders) were reported in $21(14 \%)$ and $6(4 \%)$ studies, respectively. Only Argentina, Brazil, Chile, Colombia, Costa Rica, Cuba, Mexico, and Uruguay described the types of interventions performed. Nine publications $(6 \%)$ referred to programs or policies to improve outcomes, but did not state the interventions employed. Fifty-two publications $(35 \%)$ reported baseline measures-only (BMO) studies (e.g., antimicrobial consumption or utilization, compliance with guidelines, costs, microbial susceptibility), without reporting any specific intervention.

The impacts of AMS interventions were classified into two broad categories: process $(n=84)$ and outcome $(n=169)$ measures. Process measures were included in $52(35 \%)$ publications based on adherence to guidelines and appropriateness of drug selection. Other process measures were described in $32(22 \%)$ publications, including number of interventions performed and duration. Outcome measures were subdivided into four categories: (a) antimicrobial consumption, often reported as daily defined doses or days on therapy; (b) clinical (length of stay, mortality, re-admission, survival); (c) microbiological (e.g., AMR, Clostridium difficile infections); and (d) economical (e.g., cost of strategies, savings, cost of therapy) outcomes. Seventy-one publications (48\%) measured antimicrobial consumption, followed by microbiological $(n=45)$, clinical $(n=$ $28)$, and economical $(n=25)$ outcomes. Finally, there were 59 publications $(40 \%)$ from six countries (Argentina, Brazil, Chile, Colombia, Cuba, and Mexico) that reported comprehensively on all three domains, the SPOs.

\section{DISCUSSION}

This scoping review identified 147 publications on AMS initiatives in hospitals in LAC from 1985 - 2019, 28\% of which were considered grey literature. This finding supports the premise that AMS progress does not always reach the academic literature, and that grey literature should be included in systematic reviews to describe the wider panorama of the ASPs in the region. Still, these search results may have omitted valuable AMS initiatives in LAC, ones that could not be found by this search strategy but may be reported elsewhere, such as on PROAnet (www.proanet. org), which includes slide presentations.

\section{Consistent terminology for reporting AMS initiatives}

These results describe an evolution in AMS terminology. Although the term, "antimicrobial stewardship" was published in 1996 in the United States (2), according to this study, it was not used in LAC until 2010. This could be because the term is not a straight-forward translation from English into the languages of the region. Though apparently a minor issue, using consistent language to refer to AMS is fundamental to its purpose (18). Many publications indexed under "AMS" pursue a different goal than that of achieving a rational use of antimicrobials; our exclusion criteria were designed under the premise of this functional discrimination. Also, as seen in this review, title semantics related to AMS, such as policy, program, and intervention, are imprecisely employed as synonyms. In the future, ASPs in the region should be reported with consistent terminology. Terms that have gained popularity in recent years should be acknowledged and considered as they may be closer to the original meaning and goal of antimicrobial stewardship; for example, "Programs for Optimizing the Use of Antimicrobials" (PROAs), adapted from Spain (19).

\section{Tackling antimicrobial use in hospitals: has LAC made progress?}

The increasing number of publications on the topic suggests a growing interest and commitment to tackling AMR in LAC. ASP efforts are not as ubiquitous as they are in the United States, France, or the United Kingdom (7), but increasingly LAC countries report the involvement of widely-distributed hospital networks $(20,21)$. Considering that only 18 countries have published their experience with antimicrobial stewardship initiatives, it is necessary to keep working towards extending and strengthening these efforts in the region.

According to our search, the largest countries (e.g., Brazil, Argentina, Colombia, and Mexico) have produced the most AMS publications, mainly from initiatives in capital cities. This is likely due to the higher concentration of hospitals with adequate resources in capital cities and the capacity for ASP implementation and reporting. In turn, little has been reported on AMS practices in small cities where hospitals may have $<50$ beds and where, in some countries, two-thirds of the health care force is engaged (22). AMS implementation may encounter difficulties in hospitals with limited financial and human resources, few training opportunities, and other factors $(3,23)$; however, ASPs can be tailored to the context, so long as comparable metrics are used (24).

Efforts to implement ASPs and publish these activities individually or in aggregate may shed light on specific facilitators and barriers, and are important for determining progress in the region. The numerous calls to global action by $\mathrm{PAHO} / \mathrm{WHO}$, the regional workshops, and the point-prevalence studies may have been instrumental to the ASP investments made by the countries and to the number of ASP documents published $(23,25)$.

\section{Towards comprehensive reporting of AMS elements}

To replicate AMS initiatives and allow for valuable lessons, ASP reports could benefit from comprehensively describing structure, process, and outcome elements $(26,27)$. The allocation of human resources for AMS was thought to be a limitation in LAC (3); however, most publications reviewed in this study did report having one or more AMS-participating staff members. Nevertheless, distinguishing among the various types of health professionals involved was not always possible. This may be an opportunity to gain a better understanding of roles that health professionals play in ASPs, and to see if there is a pattern in LAC $(10,28)$. Also, reporting on other structure elements, such as material resources, governance, and leadership support (not included by this review), is routinely performed by successful AMS programs (7). 
Equally as important to determining what works best in LAC, is fully describing process elements (e.g., type and duration of interventions). The most common strategy was educational interventions, considered essential to prescriber autonomy (29). Also an educational intervention, the adaptation of local guidelines (and adherence to them) is known to provide attainable success in resource-limited settings (30). Although we expected restrictive interventions to be most common in LAC, since they are easiest to implement and monitor (3), persuasive strategies were more frequently used. Both strategies have been widely cited as best practices, but there is no consensus on which works best; instead, success is defined by adapting to the context (7). Of note, a number of countries took a first step toward AMS by publishing $\mathrm{BMO}$, like the well-known point-prevalence study on antimicrobial use (4); this is important, but should be just a starting point for implementing an ASP.

Utilization of IT is a common concern in LMIC countries (4); in this study, only $14 \%$ of the total AMS initiatives involved the use of information technology, which denotes moderate progress in infrastructure investment. Some IT interventions, such as electronic records and computerized drug-ordering systems, could allow surveillance of prescribing practices and real-time assessment of ASP effectiveness; computerized decision-support systems could help prescribers to make the most adequate antimicrobial choices $(7,32)$. Also, in contrast with HICs $(7)$, laboratory and diagnostic capacities were the least used, probably because of the financial cost of maintaining supplies and the technical capabilities required to operate them (32).

Regarding the outcome elements, in countries that lack data and resources, the value of ASPs is not always reported with metrics that allow for program assessment (33). Recently published reviews $(34-36)$ showed that cost-effectiveness studies are most common in the United States and European countries. In fact, a recent review (34) showed that only one study of cost-effectiveness had been developed in LMICs. Another systematic review regarding the value of ASPs (35) included only 5 of 146 studies from South America, stressing that LAC is delayed on this issue. Similarly, the present review found that economic outcomes were the least common type of outcome reported. However, the fact that it was reported in $25(17 \%)$ of studies shows increasing attention to this issue.

Outcome measures have traditionally focused on antimicrobial consumption $(34,35)$. Along with the economical outcomes, clinical outcomes were found to be the least employed in studies from LAC. However, clinical outcomes are essential goals of ASPs and justify their long-term viability $(28,37)$. Some potential explanations for this finding are the difficulty of establishing a causal association between ASPs and clinical outcomes; poor study design of interventions (28); and scarcity of human resources, infrastructure, and funding, which limit the collection of quantity and quality metrics (33). Lastly, process measures that assess the impact of ASPs are imperative for tracking the number of interventions needed to modify an outcome, to evaluate the time between implementation and positive impact, and to track adherence to interventions, among many other ends $(27,28)$.

Limitations. Many valuable unpublished documents and informal literature may not have been captured despite our thorough search. It is fairly certain, however, that few published documents were missed and that this scoping review represents the current state of AMS and ASPs in LAC. Also, since AMS-related terminology analysis was restricted to titles, we may have omitted terminology used only in the body text of articles. Finally, although they may serve as a proxy value, publications may not be a reliable indicator of AMS activity in cities and/or countries at a point in time. AMS initiatives could not always be classified by intervention or by city, and so, some could not be mapped or counted accurately at that level.

\section{Conclusions}

Developing an AMS intervention in a resource-limited country represents a big challenge; yet, some countries in LAC have achieved successful implementation of ASPs in hospitals. This scoping review of the academic and grey literature on AMS initiatives in LAC countries found a large volume of published documents not included in previous reviews. Publications on AMS initiatives indicated that related terminology evolved over time as numbers increased. Published documents of ASPs in hospitals covered a large portion of LAC, with almost onehalf of programs located in capital cities. This review provided an overview of reported SPOs, by country, in LAC. Comprehensive inclusion of these elements is increasing, but should be required for measuring the effectiveness and progress of AMS and for replicating successful efforts in countries throughout LAC.

Author contributions. JH and AD designed the project. JH developed the search strategy. All authors participated in the screening and extraction phases. $\mathrm{JH}$ analyzed and interpreted the data. JR designed the graphic output. JH, GL, and AD wrote the manuscript. All authors reviewed and approved the final version.

\section{Conflicts of interest. None declared.}

Disclaimer. Authors hold sole responsibility for the views expressed in the manuscript, which may not necessarily reflect the opinion or policy of the RPSP/PAJPH and/or PAHO.

\section{REFERENCES}

1. Doron S, Davidson LE. Antimicrobial stewardship. Mayo Clin Proc. 2011;86(11):1113-23. Available from: https://www.ncbi.nlm.nih. gov/pmc/articles/PMC3203003/ Accessed 14 February 2020.

2. Dyar OJ, Huttner B, Schouten J, Pulcini C; ESGAP (ESCMID Study Group for Antimicrobial Stewardship). What is antimicrobial stewardship? Clin Microbiol Infect. 2017;23(11):793-8. Available from: https: / www.clinicalmicrobiologyandinfection.com/article / S1198-743X(17)30489-5/fulltext Accessed 21 October 2019.

3. Levy Hara G. Antimicrobial stewardship in hospitals: Does it work and can we do it? J Glob Antimicrob Resist. 2014;2(1):1-6. Available from: https://pubmed.ncbi.nlm.nih.gov/27873630/ Accessed 21 October 2019. 
4. World Health Organization. Antimicrobial stewardship programmes in health-care facilities in low- and middle-income countries. A WHO practical toolkit. Geneva: WHO; 2019. Available from: https://apps.who.int/iris/bitstream/handle/10665/329404 /9789241515481-eng.pdf Accessed 31 October 2019.

5. Tiong JJL, Loo JSE, Mai CW. Global antimicrobial stewardship: A closer look at the formidable implementation challenges. Front Microbiol. 2016;16(7):1860. Available from: https://www. frontiersin.org/articles/10.3389/fmicb.2016.01860/full Accessed 28 February 2020

6. MacDougall C, Polk RE. Antimicrobial stewardship programs in health care systems. Clin Microbiol Rev. 2005; 18(4):638-56. Available from: https://cmr.asm.org/content/18/4/638.short Accessed 14 February 2020.

7. Trivedi KK, Dumartin C, Gilchrist M, Wade P, Howard P. Identifying best practices across three countries: hospital antimicrobial stewardship in the United Kingdom, France, and the United States. Clin Infect Dis. 2014;59 Suppl 3:S170-8. Available from: https://academic.oup.com/cid/article/59/suppl_3/S170/317726 Accessed 14 February 2020.

8. Cox JA, Vlieghe E, Mendelson M, Wertheim H, Ndegwa L, Villegas M V et al. Antibiotic stewardship in low- and middleincome countries: the same but different? Clin Microbiol Infect. 2017;23(11):812-818. Available from: https:/ / pubmed.ncbi.nlm.nih. gov /28712667/ Accessed 21 October 2019.

9. Curcio D. On behalf of the Latin American antibiotic use in intensive care unit Group. Antibiotic prescription in intensive care units in Latin America. Rev Argent Microbiol. 2011;43(3):203-11. Available from: https://pubmed.ncbi.nlm.nih.gov/22430995/ Accessed 14 February 2020.

10. Howard P, Pulcini C, Levy Hara G, West RM, Gould IM, Harbarth $S$ et al. An international cross-sectional survey of antimicrobial stewardship programmes in hospitals. J Antimicrob Chemother. 2014;70(4):1245-55. Available from: https://academic.oup.com/ jac/article/70/4/1245/801366 Accessed 21 October 2019.

11. Van Dijck C, Vlieghe E, Cox JA. Antibiotic stewardship interventions in hospitals in low-and middle-income countries: A systematic review. Bull World Health Organ. 2018;96(4):266-80. Available from: https://www.who.int/bulletin/volumes/96/4/17-203448. pdf?ua=1 Accessed 21 October 2019

12. Bertollo LG, Lutkemeyer DS, Levin AS. Are antimicrobial stewardship programs effective strategies for preventing antibiotic resistance? A systematic review. Am J Infect Control. 2018;46(7):82436. Available from: https://pubmed.ncbi.nlm.nih.gov/29472107/ Accessed 21 October 2019.

13. Muñoz J, Motoa G, Escandón-Vargas K, Bavestrello L, Quirós R, Hernández, C, Villegas M. Current Antimicrobial Stewardship Practices in Latin America: where are we? Open Forum Infect Dis. 2015;2 Suppl 1:192. Available from: https://academic.oup.com/ ofid/article/2/suppl_1/192/2635214 Accessed 21 October 2019.

14. Pham MT, Rajić A, Greig JD, Sargeant JM, Papadopoulos A, Mcewen SA. A scoping review of scoping reviews: Advancing the approach and enhancing the consistency. Res Synth Methods 2014;5(4):371-85. Available from: https:/ / onlinelibrary.wiley.com/doi/full/10.1002/ jrsm.1123 Accessed 28 February 2020.

15. Tricco AC, Lillie E, Zarin W, O'Brien KK, Colquhoun H, Levac D, et al. PRISMA extension for scoping reviews (PRISMA-ScR): Checklist and explanation. Ann Intern Med. 2018;169(7):467-73. Available from: https://pubmed.ncbi.nlm.nih.gov/30178033/ Accessed 21 October 2019.

16. Greenhalgh T, Peacock R. Effectiveness and efficiency of search methods in systematic reviews of complex evidence: audit of primary sources BMJ 2005. 331: 1064-65. Available from: https:/ /www. ncbi.nlm.nih.gov/pmc/articles/PMC1283190/pdf/bmj33101064. pdf Accessed 30 April 2020

17. Ouzzani M, Hammady H, Fedorowicz Z, Elmagarmid A. Rayyana web and mobile app for systematic reviews. Syst Rev. 2016;5(1): 210. Available from: https://systematicreviewsjournal.biomedcentral.com/articles/10.1186/s13643-016-0384-4 Accessed 21 October 2019.

18. Mendelson M, Balasegaram M, Jinks T, Pulcini C, Sharland M. Antibiotic resistance has a language problem. Nature. 2017;545(7652):23-5. Available from: https:/ / pubmed.ncbi.nlm.nih. gov/28470219/ Accessed 21 October 2019.
19. Horcajada JP, Grau S, Paño-Pardo JR, López A, Oliver A, Cisneros JM, et al. Antimicrobial stewardship in Spain: Programs for optimizing the use of antibiotics (PROA) in Spanish hospitals. Germs. 2018;8(3):109-12. Available from: https://pubmed.ncbi.nlm.nih. gov/30250829/ Accessed 21 October 2019.

20. Quiros R, Cabral M, Bertuzzi R, Caeiro JP, Rodriguez V, Pfoh M, et al. Implementation of Antimicrobial Stewardship Programs in Adult Intensive Care Units and General Wards at Argentinean Hospitals: The PROA Project. Int J Infect Dis. 2018;73 Suppl 143. Available from: https://www.ijidonline.com/article/S12019712(18)33821-9/fulltext Accessed 21 October 2019.

21. Alvarez Moreno CA, Mantilla Borda DL. Implementation of a national surveillance program for antimicrobial use, Colombia, 2012-2013. Open Forum Infect Dis. 2014;1 Suppl 1:S75-S76. Available from: https://academic.oup.com/ofid/article/6/4/ ofz104/5430256 Accessed 21 October 2019.

22. Giacomini JL, Fortaleza CM. Use of parenteral antimicrobials in very small hospitals in inner Brazil: patterns, determinants, and opportunities for interventions in developing countries. J Hosp Infect. 2017;96(3):290-93. Available from: https:/ / pubmed.ncbi.nlm. nih.gov/28527868/ Accessed 14 February 2020.

23. Levy Hara G. Panorama sobre los Programas de Optimización de Antimicrobianos en América Latina. Boletín CONAMED. 2018;4(Especial 2018):14-6. Available from: http://www.conamed. gob.mx/gobmx/boletin/pdf/boletin22/Panorama.pdf Accessed 21 October 2019.

24. Stenehjem E, Hyun DY, Septimus E, Yu KC, Meyer M, Raj D, et al. Antibiotic stewardship in small hospitals: barriers and potential solutions. Clin Infect Dis. 2017;65(4):691-696. Available from: https: / / academic.oup.com/cid/article / 65 / 4/691/3788003 Accessed 14 February 2020.

25. Pulcini C. Antibiotic stewardship: update and perspectives. Clin Microbiol Infect. 2017;23(11):791-2. Available from: https:// www.clinicalmicrobiologyandinfection.com/article/S1198743X(17)30478-0/abstract Accessed 21 October 2019.

26. Brotherton AL. Metrics of Antimicrobial Stewardship Programs. Med Clin North Am. 2018;102(5):965-76. Available from: https:// pubmed.ncbi.nlm.nih.gov/30126585/ Accessed 14 February 2020.

27. Curcio D. Antibiotic Stewardship: The "real world" when resources are limited. Infect Control Hosp Epidemiol. 2010;31(6):666-8. Available from: https://pubmed.ncbi.nlm.nih.gov/20433352/ Accessed 14 February 2020.

28. Leuthner KD, Doern G V. Antimicrobial stewardship programs. J Clin Microbiol. 2013; 51(12):3916-20. Available from: https://jcm. asm.org/content/51/12/3916/article-info Accessed 14 February 2020.

29. Aryee A, Price N. Antimicrobial stewardship - Can we afford to do without it? Br J Clin Pharmacol. 2015;79(2):173-81. Available from: https://bpspubs.onlinelibrary.wiley.com/doi/full/10.1111/ bcp.12417 Accessed 14 February 2020.

30. Hijazi K, Joshi C, Gould IM. Challenges and opportunities for antimicrobial stewardship in resource-rich and resource-limited countries. Expert Rev Anti Infect Ther. 2019;17(8):621-34. Available from: https://www.tandfonline.com/doi/abs/10.1080/1478 7210.2019.1640602?journalCode=ierz20 Accessed 28 February 2020.

31. Davey P, Marwick CA, Scott CL, Charani E, Mcneil K, Brown E, et al. Interventions to improve antibiotic prescribing practices for hospital inpatients. Cochrane Database Syst Rev. 2017;2:CD003543. Available from: https://pubmed.ncbi.nlm.nih.gov/28178770/ Accessed 14 February 2020

32. Bebell LM, Muiru AN. Antibiotic use and emerging resistance: How can resource-limited countries turn the tide? Glob Heart. 2014;9(13):347-58. Available from: https://pubmed.ncbi.nlm.nih. gov/25667187/ Accessed 14 February 2020.

33. Akpan MR, Ahmad R, Shebl NA, Ashiru-Oredope D. A review of quality measures for assessing the impact of antimicrobial stewardship programs in hospitals. Antibiotics (Basel). 2016;5(1). pii: E5. Available from: https://www.ncbi.nlm.nih.gov/pmc/articles/ PMC4810407/ Accessed 14 February 2020.

34. Naylor NR, Zhu N, Hulscher M, Holmes A, Ahmad R, Robotham JV. Is antimicrobial stewardship cost-effective? A narrative review of the evidence. Clin Microbiol Infect. 2017; 23(11): 806-11. Available from: https://pubmed.ncbi.nlm.nih.gov/28642146/ Accessed 14 February 2020. 
35. Nathwani D, Varghese D, Stephens J, Ansari W, Martin S, Charbonneau C. Value of hospital antimicrobial stewardship programs [ASPs]: A systematic review. Antimicrob Resist Infect Control. 2019;8:35. Available from: https://aricjournal.biomedcentral.com/ articles/10.1186/s13756-019-0471-0 Accessed 14 February 2020.

36. Ibrahim, NH, Maruan, K, Mohd Khairy, HA, Hong, Y H, Dali, AF, \& Neoh, CF. Economic evaluations on antimicrobial stewardship programme: a systematic review. J Pharm Pharm Sci. 2017; 20(1): 397-406. Available from: https://www.ncbi.nlm.nih.gov/pubmed/29145934

37. Ibrahim OM, Polk RE. Antimicrobial use metrics and benchmarking to improve stewardship outcomes: Methodology, opportunities, and challenges. Infect Dis Clin North Am. 2014; 28(2):195-214. Available from: https://pubmed.ncbi.nlm.nih.gov/24857388/ Accessed 28 February 2020

Manuscript received on 4 November 2019. Revised version accepted for publication on 16 April 2020.

\section{Iniciativas de optimización del uso de antimicrobianos en los hospitales de América Latina y el Caribe: Revisión exploratoria}

RESUMEN Objetivos. Examinar las iniciativas publicadas sobre optimización del uso de antimicrobianos (OUA) en hospitales de América Latina y el Caribe para caracterizar el uso de la terminología, la geotemporalidad y algunos elementos de la estructura (recursos humanos), el proceso (intervenciones) y los resultados, así como para establecer las áreas prioritarias para mejorar la información sobre este tema.

Métodos. En esta revisión exploratoria se realizaron búsquedas en PubMed, LILACS, Embase y otras doce bases de datos, además de una búsqueda manual de la bibliografía académica y gris, con el fin de encontrar documentos acerca de las iniciativas de optimización del uso de antimicrobianos en hospitales de 33 países de América Latina y el Caribe hasta agosto del 2019. Algunas de las palabras clave fueron "antibiótico" o "antimicrobiano" Y "rectoría", "política", "estrategias", "gestión", "control", "uso racional”, "uso apropiado", "vigilancia" o "intervenciones", además de los nombres de los 33 países.

Resultados. Los artículos seleccionados sumaron 147 estudios publicados entre 1985 y el 2019, de los que en un 22 \% se mencionó la optimización del uso de antimicrobianos ('antimicrobial stewardship') en su título. Dieciocho países publicaron iniciativas de optimización del uso de antimicrobianos para hospitales, la mitad de las cuales se ejecutaron en sus ciudades capitales. Brasil, Argentina, Colombia, Cuba, México y Chile, en orden descendente según la frecuencia, constituyeron más del $59 \%$ de las iniciativas publicadas. Las intervenciones educativas fueron las que se informaron con mayor frecuencia, seguidas por las estrategias persuasivas y restrictivas. La medida de resultado notificada más comúnmente fue el consumo de antimicrobianos. Cerca de un tercio de los estudios (35\%) se refirió únicamente a las mediciones de base en preparación para las intervenciones de optimización del uso de antimicrobianos. Cincuenta y nueve estudios de seis países informaron exhaustivamente sobre las iniciativas de optimización del uso de antimicrobianos mediante elementos relativos a la estructura, el proceso y los resultados (EPR).

Conclusiones. Las iniciativas publicadas sobre la optimización del uso de antimicrobianos en los hospitales han aumentado con el transcurso del tiempo y se han ampliado en América Latina y el Caribe. Sin embargo, se necesitan más programas. Es esencial suministrar información completa de los elementos relativos a la EPR para evaluar y replicar las medidas de optimización del uso de antimicrobianos.

Palabras clave Programas de optimización del uso de los antimicrobianos; farmacorresistencia microbiana; hospitales; América Latina; Región del Caribe. 


\section{Iniciativas de Otimização do Uso de Antimicrobianos em hospitais da América Latina e Caribe: uma revisão exploratória}

RESUMO Objetivos. Examinar iniciativas publicadas sobre a otimização do uso de antimicrobianos em hospitais da América Latina e Caribe (ALC), caracterizar o uso da terminologia sobre iniciativas de otimização do uso de antimicrobianos, geotemporalidade e elementos das estruturas (recursos humanos), processos (intervenções) e resultados, bem como estabelecer áreas prioritárias para melhorar a publicação de estudos sobre iniciativas de otimização do uso de antimicrobianos.

Métodos. Realizamos uma revisão exploratória pesquisando as bases de dados PubMed, LILACS, EMBASE e outras 12, juntamente com uma pesquisa manual da literatura acadêmica e cinzenta para identificar artigos sobre iniciativas de otimização do uso de antimicrobianos em hospitais de 33 países da ALC, até agosto de 2019. Os termos de busca foram 'antibiótico' ou 'antimicrobiano' E 'gestão, políticas, estratégias, gerenciamento, controle, uso racional, uso apropriado, vigilância ou intervenções', bem como os nomes de 33 países. Resultados. Os artigos selecionados totalizaram 147 estudos publicados entre 1985 e 2019; desses, 22\% utilizaram a expressão 'iniciativas de otimização do uso de antimicrobianos' ('antimicrobial stewardship') no título. Ao todo, 18 países publicaram iniciativas hospitalares sobre otimização do uso de antimicrobianos, das quais a metade foi implementada nas capitais. Brasil, Argentina, Colômbia, Cuba, México e Chile, em frequência decrescente, constituíram >59\% das iniciativas publicadas. A maior parte dos estudos descreveu intervenções educacionais, seguidas de estratégias persuasivas e restritivas. O consumo de antimicrobianos foi o desfecho relatado com mais frequência. Cerca de um terço dos estudos (35\%) mencionou apenas medidas feitas na linha de base em preparação para as intervenções de otimização do uso de antimicrobianos. Ao todo, 59 estudos de 6 países descreveram as iniciativas de otimização do uso de antimicrobianos de forma abrangente, relatando elementos de estruturas, processos e resultados (EPR).

Conclusões. As iniciativas publicadas sobre a otimização do uso de antimicrobianos em hospitais têm aumentado ao longo do tempo, expandindo-se em toda a ALC. No entanto, é preciso desenvolver mais programas. A descrição completa de elementos de EPR é fundamental para avaliar e reproduzir as ações de otimização do uso de antimicrobianos.

Palavras-chave Gestão de antimicrobianos; resistência microbiana a medicamentos; hospitais; América Latina; Região do Caribe. 